\title{
$\mathrm{Fe}-\mathrm{Cu}$ 合金における欠陥形成の損傷速度依存性 に関するモデル計算
}

\author{
柳田誠也 1 ,*1 義家敏 ${ }^{1}$ 井野博 満 2
}

1京都大学原子炉実験所

2法政大学工学部機械工学科

J. Japan Inst. Metals, Vol. 64, No. 2 (2000), pp. 115-124 (C) 2000 The Japan Institute of Metals

\section{A Model Calculation for Irradiaton Rate Dependence of Defect Structure in Fe-Cu Alloy}

\author{
Seiya Yanagita ${ }^{1, * 1}$, Toshimasa Yoshiie ${ }^{1}$ and Hiromitsu Ino ${ }^{2}$ \\ ${ }^{1}$ Research Reactor Institute, Kyoto University, Kumatori 590-0494 \\ ${ }^{2}$ Department of Mechanical Engineering, Faculty of Engineering, Hosei University, Koganei 184-8584
}

\begin{abstract}
We performed a model calculation of damage rate dependence on defect structures and mechanical property changes in $\mathrm{Fe}-\mathrm{Cu}$ model alloy. The model was based on the rate theory, and focused on the nucleation and growth of point defect clusters and $\mathrm{Cu}$ clusters. The effect of irradiation cascade was introduced as the direct formation of small point defect clusters in cascade. We assumed that the production rate of irradiation cascade was proportional to that of Frenkel pairs. We also took into account the instability of small point defect clusters caused by thermal dissociation. We assumed that interstitials, vacancies and copper atoms were the mobile defects. From the result of this model calculation, we estimated the yield stress change in $\mathrm{Fe}-\mathrm{Cu}$ model alloy using Orowan and Russel-Brown models. The concentrations of interstitial and vacancy clusters increased with increasing the damage rate, whereas their average radii decreased. On the other hand, both of the concentration and the average radius of copper clusters increased with decreasing the damage rate. This dependence is caused by the difference in the number of jumps of vacancies before annihilation since copper atoms migrate by vacancy mechanism. The major factor of yield stress change varies depending on the damage rate. At the lower damage rate, the change is caused by the copper clusters, and at the higher damage rate, it is by the defect clusters. In the Russel-Brown model, the transition region appears around $P=10^{-8} \mathrm{dpa} / \mathrm{s}$. This transition region falls between the irradiation conditions of power and test reactors. Hence, the effect of damage rate should be carefully considered when one interpretes results of accelerated irradiation tests.
\end{abstract}

(Received August 16, 1999; In Final Form November 19, 1999)

Keywords: irradiation rate dependence, model calculation, rate theory, radiation effect, copper precipitation, the Russel-Brown model

\section{1. 緒言}

銅は $873 \mathrm{~K}$ 以下の温度では鉄中に汪とんど固溶せず，ま た鉄と銅は全組成範囲に掞いて金属間化合物を作らないの で, $\mathrm{Fe}-\mathrm{Cu}$ 合金を時効すると銅が析出する. 原子炉圧力容 器の材料である低合金鋼中に銅が含まれていると，原子炉運 転中に受ける中性子照射のために, 通常では拡散が遅くて析 出が起こらないよらな低温 $(\sim 573 \mathrm{~K})$ で銅が析出し, 材料の 脆化を引き起こす．日本の原子炉の圧力容器鋼に含まれる銅 濃度の年次変化が文献1)に示されているが，これを見ると， 一般に建造年代の古い原子炬圧力容器注ど材料中の銅濃度が 高い，それら古い原子炉に执いては，銅の析出の影響はより 重大である。

照射による材料の性質の変化を事前に予測するために，加

*1 京都大学大学院生; 大学院工学研究科機械物理工学専攻 (Graduate Student, Kyoto University; Department of Engineering Physics and Mechanics, Graduate School of Engineering)
速照射試験が行われている。これは実際よりも大きな損傷速 度で照射を行って, その組織・性質の变化から実際の圧力容 器の性質の変化を予測するものである。この方法は,「等し い量の照射を受けた同質の材料の性質変化は, 損傷速度によ らずほぼ等しい」といらことを前提にしている。しかし， Gundremmingen 原子炉の圧力容器鋼材の試験結果 ${ }^{2-4)}$, HFIRに打ける異常脆化の実験結果5) は, 久陥形成に関して 照射量のみでなく，損傷速度もまた重要なパラメータである 可能性を強く示唆し, 多くの研究者の関心を引いた．損傷速 度依存性を中心に取り扱った研究としては, Kiritani の研 究6), Stoller の研究 ${ }^{7,8)}$ な゙がある. また, 日本原子力学会 の一連の報告書9)においては, 損傷速度依存性に加光て鉄中 の銅原子の挙動に関する研究結果が報告されている.

損傷速度や照射時の温度など，照射条件の制御の難しさに 起因する材料照射実験の困難を補ら手法として, モデル計算 が行われている．材料照射実験を対象としたモデル計算は, 例えば Sizmann の研究10)などのように, 以前から行われて きたが，計算機の性能が向上した近年は，より盛んに行われ るよらになった。本研究は, $\mathrm{Fe}-\mathrm{Cu}$ 合金について, 反応速 
度論に基ついた点欠陥反応のモデルを作成し，損傷速度を変 えた場合の点欠陥执よびその集合体の濃度・大きさの変化を 調べることを目的とする。 また，計算結果をもとにして， Orowan モデル11)执よび Russel-Brown モデル12)に基づく降 伏応力変化の評価も行ら.

\section{2. 計算モデル}

\section{1 原子空孔・格子間原子およびそのクラスターに関する} 式

\section{1 .1 原子空孔の濃度 $C_{\mathrm{V}}$ および格子間原子の濃度 $C_{\mathrm{I}}$ の時 間変化}

原子空孔と格子間原子のみが移動可能とすると，それらの 濃度の照射下に和ける時間变化は以下のようになる。

$$
\begin{aligned}
\frac{\mathrm{d} C_{\mathrm{V}}}{\mathrm{d} t}= & P_{\mathrm{V}}-C_{\mathrm{s}} M_{\mathrm{V}} C_{\mathrm{V}}-Z_{\mathrm{I}, \mathrm{V}}\left(M_{\mathrm{I}}+M_{\mathrm{V}}\right) C_{\mathrm{I}} C_{\mathrm{V}} \\
& -2 Z_{\mathrm{V}, \mathrm{V}} C_{\mathrm{V}} M_{\mathrm{V}} C_{\mathrm{V}}-Z_{\mathrm{V},{ }_{\mathrm{V}}} C_{\mathrm{VC}} M_{\mathrm{V}} C_{\mathrm{V}}-Z_{\mathrm{V}, \mathrm{IC}} C_{\mathrm{IC}} M_{\mathrm{V}} C_{\mathrm{V}} \\
& -Z_{\mathrm{V}, \mathrm{V}_{2}} C_{\mathrm{V}_{2}} M_{\mathrm{V}} C_{\mathrm{V}}-Z_{\mathrm{V}, \mathrm{I}_{2}} C_{\mathrm{I}_{2}} M_{\mathrm{V}} C_{\mathrm{V}}+Z_{\mathrm{I}, \mathrm{V}_{2}} C_{\mathrm{V}_{2}} M_{\mathrm{I}} C_{\mathrm{I}} \\
& -Z_{\mathrm{V}, \mathrm{V}_{3}} C_{\mathrm{V}_{3}} M_{\mathrm{V}} C_{\mathrm{V}}-Z_{\mathrm{V}, \mathrm{I}_{3}} C_{\mathrm{I}_{3}} M_{\mathrm{V}} C_{\mathrm{V}}+2 Z_{\mathrm{V}_{2}} B_{\mathrm{V}_{2}} M_{\mathrm{V}} C_{\mathrm{V}_{2}} \\
& +Z_{\mathrm{V}_{3}} B_{\mathrm{V}_{3}} M_{\mathrm{V}} C_{\mathrm{V}_{3}} \\
\frac{\mathrm{d} C_{\mathrm{I}}=}{\mathrm{d} t} & P_{\mathrm{I}}-C_{\mathrm{s}} M_{\mathrm{I}} C_{\mathrm{I}}-Z_{\mathrm{I}, \mathrm{V}}\left(M_{\mathrm{I}}+M_{\mathrm{V}}\right) C_{\mathrm{I}} C_{\mathrm{V}} \\
& -2 Z_{\mathrm{I}, \mathrm{I}} C_{\mathrm{I}} M_{\mathrm{I}} C_{\mathrm{I}}-Z_{\mathrm{I}, \mathrm{IC}} C_{\mathrm{IC}} M_{\mathrm{I}} C_{\mathrm{I}}-Z_{\mathrm{I}, \mathrm{VC}} C_{\mathrm{V} C} M_{\mathrm{I}} C_{\mathrm{I}} \\
& -Z_{\mathrm{I}, \mathrm{I}_{2}} C_{\mathrm{I}_{2}} M_{\mathrm{I}} C_{\mathrm{I}}-Z_{\mathrm{I}, \mathrm{V}_{2}} C_{\mathrm{V}_{2}} M_{\mathrm{I}} C_{\mathrm{I}}+Z_{\mathrm{V}, \mathrm{I}_{2}} C_{\mathrm{I}_{2}} M_{\mathrm{V}} C_{\mathrm{V}} \\
& -Z_{\mathrm{I}, \mathrm{I}_{3}} C_{\mathrm{I}_{3}} M_{\mathrm{I}} C_{\mathrm{I}}-Z_{\mathrm{I}, \mathrm{V}_{3}} C_{\mathrm{V}_{3}} M_{\mathrm{I}} C_{\mathrm{I}}+2 Z_{\mathrm{I}_{2}} B_{\mathrm{I}_{2}} M_{\mathrm{I}} C_{\mathrm{I}_{2}} \\
& +Z_{\mathrm{I}_{3}} B_{\mathrm{I}_{3}} M_{\mathrm{I}} C_{\mathrm{I}_{3}}
\end{aligned}
$$

右辺第 1 項は照射による点欠陥の生成率 (損傷率)を表し ている．本モデルでは点欠陉はフレンケル対として生成する と考えているので, 単位時間あたりのフレンケル対の生成数 を $P$ とすると， $P_{\mathrm{V}}=P_{\mathrm{I}}=P$ である，V は原子空孔，Iは格子 間原子を意味する添字である，第 2 項は点欠陥の静的シン クでの消滅を表している．静的シンクとは，転位や結晶粒界 などのよらに，材料中にはじめから存在し，かつ照射中にそ の濃度およびシンク強度が変化しないものを指す。計算点を 半径 $1 \times 10^{5}$ 原子間距離の結晶粒の中心点と仮定すると, 点 欠陥が粒界で消隇するのに必要な移動の回数は $\left(10^{5}\right)^{2}=10^{10}$ 回程度と考えられるので, $C_{\mathrm{s}}$ の值はこの逆数を取って $C_{\mathrm{s}}=$ $10^{-10}$ とした ${ }^{13)}$. 第 3 項は対消隇項である. $Z$ は反応サイト の数を表す定数で, 例えば $Z_{\mathrm{I}, \mathrm{V}}$ は格子間原子と原子空孔之 の反応に执ける反応サイト数を表す，以下同様の表記を用い る.第 4 項は点欠陥対の形成を表している. 第 5 項および 第 6 項は点欠陥クラスターによる吸収項である。点欠陥ク ラスター・点欠陥複合体については後述する， $C_{\mathrm{VC}}$ および $C_{\mathrm{IC}}$ はそれぞれ原子空孔クラスターの濃度扎よび格子間原子 クラスターの濃度を表している。第 5 項がクラスターへの 同種の点欠陥の吸収を，第 6 項が異種点欠陥クラスターヘ の吸収を表す．第 7 項は点欠陷対と結合して tri-vacancy や tri-interstitial を作る反応を，第 8 項は異種点欠陌対に吸収 される反応を, 第 9 項は第 8 項とは逆に, 点欠陥対と異種 点欠陥が反応する結果点欠陥が生成することを，それぞれ表 している. 第10項, 第11項は, tri-vacancy または tri-interstitial と点欠陥との反応を表している．第10項が表す反応
は，同種の点欠陥複合体と結合して安定な点欠陥クラスター 核を形成する反応である，第 11 項が表す反応は，異種の点 欠陥複合体と結合して，複合体を点欠陥対にする反応であ る.第12項执よび第13項は点欠陥複合体の解離反応を表し ている、第12項は点欠陥対の解離を, 第13項は tri-vacancy （または tri-interstitial）からの解離を，それぞれ表している. ここで $B=\exp \left[-E_{\mathrm{B}} /\left(k_{\mathrm{B}} T\right)\right]$ は点欠陷複合体が結合を切る 頻度を表す。 $k_{\mathrm{B}}$ はボルッマン定数， $T$ は絶対温度である. 結合エネルギー $E_{\mathrm{B}}=0$ であれば $B=1$ で， $E_{\mathrm{B}}$ が大きくなる と $B$ は小さくなり, 結合は切れにくくなる.

\section{1 .2 点欠陥集合体の濃度の時間変化}

原子空孔集合体は，原子空孔複合体(原子空孔対, trivacancy) 招よび原子空孔クラスター(構成原子空孔数が 4 個 以上のもの）に分けた。同様に，格子間原子集合体も，格子 間原子複合体扣よび格子間原子クラスターに分けた，点欠陥 複合体と点欠陥クラスターとの違いは, 前者は熱的に解離し らるのに対し, 後者は熱的に解離することはないと仮定して いる点にある，点欠陥クラスターとしては，原子空孔につい てはボイドを, 格子間原子については格子間原子型転位ルー プ(以下転位ループ)を仮定し，構成粒子数による区別をせ ず, 点欠陥クラスター内の平均粒子数が増減するとして扱 う。点欠陷クラスタ一の点欠陥の吸収に扣いては, 点欠陷ク ラスタ一近傍の点欠陷の平衡濃度を 0 と仮定した。

原子空孔対の濃度 $C_{\mathrm{V}_{2}}$ 㧊よび格子間原子対の濃度 $C_{\mathrm{I}_{2}}$ の時 間変化は, 以下のようになる。

$$
\begin{aligned}
\frac{\mathrm{d} C_{\mathrm{V}_{2}}=}{\mathrm{d} t}= & Z_{\mathrm{V}, \mathrm{V}} C_{\mathrm{V}} M_{\mathrm{V}} C_{\mathrm{V}}-Z_{\mathrm{V}, \mathrm{V}_{2}} C_{\mathrm{V}_{2}} M_{\mathrm{V}} C_{\mathrm{V}}-Z_{\mathrm{I}, \mathrm{V}_{2}} C_{\mathrm{V}_{2}} M_{\mathrm{I}} C_{\mathrm{I}} \\
& -Z_{\mathrm{V}_{2}} B_{\mathrm{V}_{2}} M_{\mathrm{V}} C_{\mathrm{V}_{2}}+Z_{\mathrm{V}_{3}} B_{\mathrm{V}_{3}} M_{\mathrm{V}} C_{\mathrm{V}_{3}}+Z_{\mathrm{I}, \mathrm{V}_{3}} C_{\mathrm{V}_{3}} M_{\mathrm{I}} C_{\mathrm{I}} \\
\frac{\mathrm{d} C_{\mathrm{I}_{2}}=}{\mathrm{d} t} & Z_{\mathrm{I}, \mathrm{I}} C_{\mathrm{I}} M_{\mathrm{I}} C_{\mathrm{I}}-Z_{\mathrm{I}, \mathrm{I}_{2}} C_{\mathrm{I}_{2}} M_{\mathrm{I}} C_{\mathrm{I}}-Z_{\mathrm{V}, \mathrm{I}_{2}} C_{\mathrm{I}_{2}} M_{\mathrm{V}} C_{\mathrm{V}} \\
& -Z_{\mathrm{I}_{2}} B_{\mathrm{I}_{2}} M_{\mathrm{I}} C_{\mathrm{I}_{2}}+Z_{\mathrm{I}_{3}} B_{\mathrm{I}_{3}} M_{\mathrm{I}} C_{\mathrm{I}_{3}}+Z_{\mathrm{V}, \mathrm{I}_{3}} C_{\mathrm{I}_{3}} M_{\mathrm{V}} C_{\mathrm{V}}
\end{aligned}
$$

tri-vacancy の濃度 $C_{\mathrm{V}_{3}}$ 抒よび tri-interstitial の濃度 $C_{\mathrm{I}_{3}}$ の 時間変化は, 以下のようになる.

$$
\begin{aligned}
\frac{\mathrm{d} C_{\mathrm{V}_{3}}}{\mathrm{~d} t}= & Z_{\mathrm{V}, \mathrm{V}_{2}} C_{\mathrm{V}_{2}} M_{\mathrm{V}} C_{\mathrm{V}}-Z_{\mathrm{V}, \mathrm{V}_{3}} C_{\mathrm{V}_{3}} M_{\mathrm{V}} C_{\mathrm{V}}-Z_{\mathrm{I}, \mathrm{V}_{3}} C_{\mathrm{V}_{3}} M_{\mathrm{I}} C_{\mathrm{I}} \\
& -Z_{\mathrm{V}_{3}} B_{\mathrm{V}_{3}} M_{\mathrm{V}} C_{\mathrm{V}_{3}}+P_{\mathrm{VC}} \\
\frac{\mathrm{d} C_{\mathrm{I}_{3}}}{\mathrm{~d} t}= & Z_{\mathrm{I}, \mathrm{I}_{2}} C_{\mathrm{I}_{2}} M_{\mathrm{I}} C_{\mathrm{I}}-Z_{\mathrm{I}, \mathrm{I}_{3}} C_{\mathrm{I}_{3}} M_{\mathrm{I}} C_{\mathrm{I}}-Z_{\mathrm{V}, \mathrm{I}_{3}} C_{\mathrm{I}_{3}} M_{\mathrm{V}} C_{\mathrm{V}} \\
& -Z_{\mathrm{I}_{3}} B_{\mathrm{I}_{3}} M_{\mathrm{I}} C_{\mathrm{I}_{3}}+P_{\mathrm{IC}}
\end{aligned}
$$

式 (5)，(6)の右辺第 5 項によって，カスケードによる点 欠陥クラスタ一核の直接形成の効果を取り入れる. 1 つの レンケル対の形成に対してどれだけのクラスター核が形成さ れるかを考光, その割合をカスケード/点欠陥比(Cascade/Point Defect Production Ratio, $r_{\mathrm{CP}}$, 以下 C/P 比) よょ ぶことにする。これを用いると，単位時間あたりの点欠陥ク ラスター核の生成数は， $P_{\mathrm{VC}}=r_{\mathrm{CP}} P, P_{\mathrm{IC}}=r_{\mathrm{CP}} P$ と書ける。本 モデルでは, カスケードによって, 点欠陷 3 個で構成され る点欠陷複合体が形成されると仮定している. カスケードに よって形成された核もまた異種点欠陉の吸收によって熱的に 壊れることを取り入れるために，クラスタ一核の大きさを 3 個とした。この仮定が結果に本質的な影響を及ぼすことはな いと考光られる。 
ボイド濃度 $C_{\mathrm{VC}}$ 抌よび転位ループ濃度 $C_{\mathrm{IC}}$ の時間変化は 以下のようになる.

$$
\begin{aligned}
& \frac{\mathrm{d} C_{\mathrm{VC}}}{\mathrm{d} t}=Z_{\mathrm{V}, \mathrm{V}_{3}} C_{\mathrm{V}_{3}} M_{\mathrm{V}} C_{\mathrm{V}} \\
& \frac{\mathrm{d} C_{\mathrm{IC}}}{\mathrm{d} t}=Z_{\mathrm{I}, \mathrm{I}_{3}} C_{\mathrm{I}_{3}} M_{\mathrm{I}} C_{\mathrm{I}}
\end{aligned}
$$

前述のように，カスケードによって形成された点欠陥複合 体の熱的な不安定性を考えるため，カスケードによる安定な 点欠陷クラスターの直接形成は考慮しなかった．そのため, 点欠陥クラスターの濃度变化は, 点欠陥の吸収によって形成 される項のみとなる。

また，単位時間あたりに点欠陥クラスターに流れ込んでく る原子空孔执よび格子間原子の数から，ボイド中に含まれる 原子空孔の総数 $R_{\mathrm{V}}$ および転位ループ中に含まれる格子間原 子の総数 $R_{\mathrm{I}}$ の時間変化を以下のように求めることができる.

$$
\begin{aligned}
& \frac{\mathrm{d} R_{\mathrm{V}}}{\mathrm{d} t}=Z_{\mathrm{V},{ }_{\mathrm{vC}}} C_{\mathrm{VC}} M_{\mathrm{V}} C_{\mathrm{V}}-Z_{\mathrm{I}, \mathrm{VC}} C_{\mathrm{VC}} M_{\mathrm{I}} C_{\mathrm{I}}+4 \frac{\mathrm{d} C_{\mathrm{VC}}}{\mathrm{d} t} \\
& \frac{\mathrm{d} R_{\mathrm{I}}}{\mathrm{d} t}=Z_{\mathrm{I}, \mathrm{IC}} C_{\mathrm{IC}} M_{\mathrm{I}} C_{\mathrm{I}}-Z_{\mathrm{V},{ }_{\mathrm{IC}}} C_{\mathrm{IC}} M_{\mathrm{V}} C_{\mathrm{V}}+4 \frac{\mathrm{d} C_{\mathrm{IC}}}{\mathrm{d} t}
\end{aligned}
$$

式 (9), (10)の右辺第 1 項と第 2 項は, 既存の点欠陥クラ スターが同種(異種)の点欠陥を吸収する効果を表し，第 3 項は, 安定な点欠陥クラスターの形成の効果を表している.

\section{2 銅原子および銅クラスターに関する式}

\subsection{1 銅原子の濃度 $C_{\mathrm{Cu}}$ の時間変化}

銅原子は空孔との位置交換によってのみ移動すると仮定す ると，照射下に拈ける銅原子濃度の時間変化は次のようにな る。

$$
\begin{aligned}
\frac{\mathrm{d} C_{\mathrm{Cu}}}{\mathrm{d} t}= & -2 Z_{\mathrm{Cu}, \mathrm{Cu}} C_{\mathrm{Cu}} M_{\mathrm{V}} C_{\mathrm{V}} C_{\mathrm{Cu}}-Z_{\mathrm{Cu}, \mathrm{CuC}} C_{\mathrm{CuC}} M_{\mathrm{V}} C_{\mathrm{V}} C_{\mathrm{Cu}} \\
& -Z_{\mathrm{Cu}_{\mathrm{Cu}}{ }_{3}} C_{\mathrm{Cu}_{3}} M_{\mathrm{V}} C_{\mathrm{V}} C_{\mathrm{Cu}}-Z_{\mathrm{Cu}_{\mathrm{Cu}} C_{2}} C_{\mathrm{Cu}_{2}} M_{\mathrm{V}} C_{\mathrm{V}} C_{\mathrm{Cu}} \\
& +2 Z_{\mathrm{V}, \mathrm{Cu}_{2}} B_{\mathrm{Cu}_{2}} M_{\mathrm{V}} C_{\mathrm{V}} C_{\mathrm{Cu}_{2}}+Z_{\mathrm{Cu}_{3}} B_{\mathrm{Cu}_{3}} M_{\mathrm{V}} C_{\mathrm{V}} C_{\mathrm{Cu}_{3}}
\end{aligned}
$$

$\mathrm{bcc}$ 鉄中の銅の拡散の活性化エネルギー $\left(E_{\mathrm{f}}+E_{\mathrm{m}}\right)$ は $4.0 \times$ $10^{-19} \sim 4.2 \times 10^{-19} \mathrm{~J}$ と実測されている14)15).この值は, 鉄 の自己拡散の值 $4.1 \times 10^{-19} \mathrm{~J}^{15)}$ とほとんど等しいので, bcc 鉄中の銅の移動の活性化エネルギー $E_{\mathrm{m}}$ は, 鉄のそれと等し $く 1.6 \times 10^{-19} \mathrm{~J}$ とした.これは，銅原子と原子空孔との間 の結合エネルギー $E_{\mathrm{B}}$ を無視することを意味する．鉄中の銅 原子の体積は鉄原子の体積よりも $9 \%{ }^{16)} \sim 15 \%{ }^{17)}$ 大きく, $E_{\mathrm{B}}$ の大きさも $1.6 \times 10^{-20} \mathrm{~J}$ 程度と推測されているが，正確 には不明であり，簡単のためにこのような仮定を置いた。 $E_{\mathrm{B}}$ を考慮すると, 拡散に寄与する空孔の数が減るので, 銅 の析出はその分遅れると考えられる。しかし， $E_{\mathrm{B}}=1.6 \times$ $10^{-20} \mathrm{~J}$, 温度 $T=573 \mathrm{~K}$ のとき, その因子は $\exp \left[E_{\mathrm{B}} /\right.$ $\left.\left(k_{\mathrm{B}} T\right)\right] \sim 8$ 程度であり, 銅濃度 $6.0 \times 10^{-3}$ をかけると実質 的な寄与は $0.048 \ll 1$ となり，本質的影響はない，以上の仮 定を置くと，モデルは単純化され，単位時間あたりの銅原子 のジャンプ頻度は, 原子空孔のジャンプ頻度 $M_{\mathrm{V}}$ と原子空孔 濃度 $C_{\mathrm{V}}$ の積で与えることができる. 本モデルで考えている 初期銅原子濃度では, 銅原子の析出に必要な拡散距離は静的 シンクへの拡散距離より短いと考えられるので, 銅原子と静 的シンクとの相互作用は考慮しなかった。
式(11)右辺第 1 項は銅原子対の形成反応を，第 2 項は銅 クラスターへの吸収反応を，第 3 項は tri- $\mathrm{Cu}$ が銅原子を吸 収して銅クラスターになる反応を，第 4 項は銅原子対が銅 原子を吸収して tri-Cuになる反応を，それぞれ表している. 本モデルに拈いては，銅クラスターとして，4 個以上の銅原 子よりなる球状の銅析出物を仮定した. これら各項の考え方 は, 式 ( 1 ), ( 2 ) と同じである. 第 5 項は銅原子対の解離反 応を, 第 6 項は tri-Cu の解離反応を表す。銅原子複合体の 解離は，原子空孔が銅原子複合体に飛び込むことによって起 こると考えている.なお，このときの原子空孔濃度は変わら ない.

\subsection{2 銅原子集合体の濃度の時間変化}

銅原子集合体についても, 原子空孔・格子間原子と同様, 銅原子対, tri- $\mathrm{Cu}$, 銅クラスターに分けた。銅原子対の濃度 $C_{\mathrm{Cu}_{2}}$ および tri-Cu の濃度 $C_{\mathrm{Cu}_{3}}$ の時間変化は以下のようにな る.

$$
\begin{aligned}
\frac{\mathrm{d} C_{\mathrm{Cu}_{2}}}{\mathrm{~d} t}= & Z_{\mathrm{Cu}, \mathrm{Cu}} C_{\mathrm{Cu}} M_{\mathrm{V}} C_{\mathrm{V}} C_{\mathrm{Cu}}-Z_{\mathrm{Cu}, \mathrm{Cu}_{2}} C_{\mathrm{Cu}_{2}} M_{\mathrm{V}} C_{\mathrm{V}} C_{\mathrm{Cu}} \\
& -Z_{\mathrm{V}, \mathrm{Cu}_{2}} B_{\mathrm{Cu}_{2}} M_{\mathrm{V}} C_{\mathrm{V}} C_{\mathrm{Cu}_{2}}+Z_{\mathrm{V}, \mathrm{Cu}_{3}} B_{\mathrm{Cu}_{3}} M_{\mathrm{V}} C_{\mathrm{V}} C_{\mathrm{Cu}_{3}} \\
\frac{\mathrm{d} C_{\mathrm{Cu}_{3}}=}{\mathrm{d} t}= & Z_{\mathrm{Cu}, \mathrm{Cu}_{2}} C_{\mathrm{Cu}_{2}} M_{\mathrm{V}} C_{\mathrm{V}} C_{\mathrm{Cu}}-Z_{\mathrm{Cu}_{\mathrm{Cu}} 3} C_{\mathrm{Cu}_{3}} M_{\mathrm{V}} C_{\mathrm{V}} C_{\mathrm{Cu}} \\
& -Z_{\mathrm{V}, \mathrm{Cu}_{3}} B_{\mathrm{Cu}_{3}} M_{\mathrm{V}} C_{\mathrm{V}} C_{\mathrm{Cu}_{3}}
\end{aligned}
$$

本研究で考えている銅原子の初期濃度は低く，木た銅クラ スターは銅原子の拡散だけで析出すると考えているので, tri-Cuについては, 式( 5 )や式 (6)のよらに, カスケード による複合体の直接形成は考えない。

銅クラスターの濃度 $C_{\mathrm{CuC}}$ の時間変化および全銅クラスタ 一中に含まれる銅原子の総数 $R_{\mathrm{Cu}}$ の時間変化は, 以下のよ らになる。

$$
\begin{aligned}
& \frac{\mathrm{d} C_{\mathrm{CuC}}}{\mathrm{d} t}=Z_{\mathrm{Cu}, \mathrm{Cu}_{3}} C_{\mathrm{Cu}_{3}} M_{\mathrm{V}} C_{\mathrm{V}} C_{\mathrm{Cu}} \\
& \frac{\mathrm{d} R_{\mathrm{Cu}}}{\mathrm{d} t}=Z_{\mathrm{Cu}, \mathrm{CuC}} C_{\mathrm{CuC}} M_{\mathrm{V}} C_{\mathrm{V}} C_{\mathrm{Cu}}+4 \frac{\mathrm{d} C_{\mathrm{CuC}}}{\mathrm{d} t}
\end{aligned}
$$

式(14)，(15)の構成は, 原子空孔·格子間原子複合体の場合 （式 $(7) \sim(10))$ と同様である.

\section{3 モデル計算で使用したその他の式および定数}

原子空孔, 格子間原子, 銅原子の単位時間あたりのジャン プ回数(移動度) は, それぞれ $M_{\mathrm{V}}=v_{0} \exp \left[-E_{\mathrm{V}}^{\mathrm{M}} /\left(k_{\mathrm{B}} T\right)\right]$, $M_{\mathrm{I}}=v_{0} \exp \left[-E_{\mathrm{I}}^{\mathrm{M}} /\left(k_{\mathrm{B}} T\right)\right], M_{\mathrm{Cu}}=M_{\mathrm{V}} \times C_{\mathrm{V}}$ である。致は， 単位時間あたりの点欠陥の熱振動の回数である. $k_{\mathrm{B}}$ はボル ッマン定数 $\left(1.38 \times 10^{-23} \mathrm{~J} / \mathrm{K}\right), T$ は温度である。本計算で は, 軽水炉の運転温度 (BWR で $561 \mathrm{~K}, \mathrm{PWR} て ゙ 588 \mathrm{~K})$ を考 慮して, 温度を $573 \mathrm{~K}$ とした。本モデル計算に括いて使用 した定数を, Table 1 にまとめて示す. 反応サイトの数 $Z$ は, 文献18) と同様の考方方で，その位置や形態に応じて，

$Z_{\mathrm{I}, \mathrm{V}}=100 ; Z_{\mathrm{V}, \mathrm{v}}=7, Z_{\mathrm{I}, \mathrm{I}}=5.5, Z_{\mathrm{Cu}, \mathrm{Cu}}=7$,

$Z_{\mathrm{I}, \mathrm{IC}}=f \times Z_{\mathrm{IC}}^{0} \pi \sqrt{N_{\mathrm{IC}}}, Z_{\mathrm{V}, \mathrm{IC}}=Z_{\mathrm{IC}}^{0} \pi \sqrt{N_{\mathrm{IC}}}, Z_{\mathrm{I}, \mathrm{VC}}=4 Z_{\mathrm{VC}}^{0} N_{\mathrm{VC}}^{2 / 3}$,

$Z_{\mathrm{V}, \mathrm{vC}}=4 Z_{\mathrm{vC}}^{0} N_{\mathrm{vC}}^{2 / 3}, Z_{\mathrm{Cu}, \mathrm{CuC}}=4 Z_{\mathrm{CuC}}^{0} N_{\mathrm{CuC}}^{2 / 3}$

とした. ここで $Z_{\mathrm{IC}}^{0}=3.5 / \sqrt{N_{\mathrm{IC}}}+2$ は格子間原子クラスター の外周の単位長さあたりの反応サイト数, また $Z_{\mathrm{VC}}^{0}=6 /$ $\sqrt{N_{\mathrm{VC}}}+1$ および $Z_{\mathrm{CuC}}^{0}=6 / \sqrt{N_{\mathrm{CuC}}}+1$ は原子空孔クラスター 
Table 1 Physical parameters used in this model.

\begin{tabular}{lcclcc}
\hline \multicolumn{1}{c}{ Parameter } & Symbol & Value & \multicolumn{1}{c}{ Parameter } & Symbol & Value \\
\hline Migration energy (I)/J & $E_{\mathrm{I}}^{\mathrm{M}}$ & $4.8 \times 10^{-20}$ & Migration energy (V)/J & $E_{\mathrm{V}}^{\mathrm{M}}$ & $1.6 \times 10^{-19}$ \\
Binding energy (di-I)/J & $E_{\mathrm{I}}^{\mathrm{B}}$ & $1.1 \times 10^{-19}$ & Binding energy (di-V)/J & $E_{\mathrm{V}}^{\mathrm{B}}$ & $4.0 \times 10^{-20}$ \\
Binding energy (tri-I)/J & $E_{\mathrm{I}_{3}}^{\mathrm{B}}$ & $1.8 \times 10^{-19}$ & Binding energy (tri-V)/J & $E_{\mathrm{V}_{3}}^{\mathrm{B}}$ & $1.2 \times 10^{-19}$ \\
Binding energy (di-Cu)/J & $E_{\mathrm{Cu}}^{\mathrm{B}}$ & $8.0 \times 10^{-21}$ & Vacancy formation energy $/ \mathrm{J}$ & $E_{\mathrm{V}}^{\mathrm{F}}$ & $2.4 \times 10^{-19}$ \\
Binding energy (tri-Cu)/J & $E_{\mathrm{Cu}}^{\mathrm{B}}$ & $1.6 \times 10^{-20}$ & Bias factor & $f$ & 1.1 \\
Cascade formation ratio & $r_{\mathrm{CP}}$ & 0.001 & Jump frequency $/ \mathrm{s}^{-1}$ & $v_{0}$ & $1 \times 10^{13}$ \\
\hline
\end{tabular}

および銅クラスターの単位表面積あたりの反応サイト数であ る. 点欠陥複合体に関する $Z$ の值は, 上記の式で $N=2$ あ るいは $N=3$ のときの值とした。各点欠陥の移動の活性化工 ネルギーは，格子間原子については $4.8 \times 10^{-20} \mathrm{~J}$ ，原子空孔 については $1.6 \times 10^{-20} \mathrm{~J}$ とた。原子空孔複合体执よび格 子間原子複合体の結合エネルギーについては, 文献19)の近 似式をもとに計算した。原子空孔濃度の初期値は, Table 1 に示した原子空孔の形成エネルギーから $6.4 \times 10^{-14}$, 銅原 子濃度の初期值は $6.0 \times 10^{-3}$ とし，その他の濃度の初期值に ついては事実上 0 で数值計算の際に不都合の生じない $1.0 \times$ $10^{-50}$ とした. 数值計算は, Gear 法による連立一次微分方程 式計算ソフト $\mathrm{CVODE}^{20)}$ を用いて行った.

\section{4 降伏応力変化の計算方法}

以上述べたモデルについて行った計算の結果をもとに，材 料の降伏応力変化を計算した. 本研究では, 材料の降伏応力 変化をOrowan モデル打よび Russel-Brown モデルを用い て計算し，その損傷速度依存性を調べた。

Orowan モデル11)では，障害物を転位がその中を進むこと のできない強い障害物と考光，そのような強い障害物の存在 による降伏応力の変化を

$$
\Delta \sigma_{\mathrm{y}}=\frac{2 G b}{\beta \bar{l}}=\frac{2 G b}{\beta} \sqrt{N d}
$$

で与えられるとする．ここで， $G$ は剛性率， $b$ はバーガース ベクトルの大ささ, $\bar{l}=(N d)^{-0.5}$ は障害物間の平均距離, $N$ は障害物の数密度, $d$ は障害物の平均直径, $\beta$ は障害物の種 類によって変わる定数である．障害物の種類が複数ある場合 は，障害物ごとに $N, d, \beta$ が異なるので,

$$
\Delta \sigma_{\mathrm{y}}=\sqrt{\sum_{i}\left(\frac{2 G b \sqrt{N_{i} d_{i}}}{\beta_{i}}\right)^{2}}
$$

とする7).ここで $i$ は障害物の種類を表す．定数の值は文 献7,8)とよった。

Russel-Brown モデル12) とは，母相と析出物の剛性率の違 いが転位の運動の障害となり，せん断応力変化を引き起こす としたモデルである，運動する転位が刃状転位の場合，降伏 応力変化 $\Delta \sigma_{\mathrm{y}}$ は次のようになる.

$$
\begin{aligned}
& \Delta \sigma_{\mathrm{y}}=\frac{2 G b}{\bar{l}}\left(1-\frac{E_{\mathrm{ppt}}}{E}\right)^{0.75} \\
& \frac{E_{\mathrm{ppt}}}{E}=\frac{1}{\ln \left(r_{\mathrm{c}} / r_{0}\right)}\left[\frac{(1-v) G_{\mathrm{ppt}}}{\left(1-v_{\mathrm{ppt}}\right) G} \ln \left(\frac{r_{\mathrm{ppt}}}{r_{0}}\right)+\ln \left(\frac{r_{\mathrm{c}}}{r_{\mathrm{ppt}}}\right)\right]
\end{aligned}
$$

らせん転位の場合は， $(1-v) /\left(1-v_{\mathrm{ppt}}\right)$ を取る. 式中の定 数のらち, $v$ はポアソン比, $r_{0}$ は転位の内側のカットオフ半 径, $r_{\mathrm{c}}$ は転位の外側のカットオフ半径, $E$ は単位長さあたり
の転位のエネルギーで, $G, b, \bar{l}$ は式(16)に出てきたものと 同じである．下添字の ppt は析出物に関するものを，下添 字のないものは母相に関するものを，それぞれ表す．計算方 法拈よび定数の值は文献8にとよった。

\section{3. 計 算 結 果}

\section{1 点欠陥およびそのクラスターに関する損傷速度依存性}

まず，鉄の点欠陥(格子間原子・原子空孔)执よびそのクラ スター(転位ループ・ボイド)についての結果を示し, 銅扣よ び銅クラスターの形成についての計算結果については後述す る。

以下に示す図に拈いて, 図中の数字は損傷速度 (Damage Rate)または中性子総照射量(Total Dose)を表しているが， 単位として用いられている dpa (displacement per atom)と は点欠陥の数の系全体に対する割合を意味し， dpa/s は単位 時間あたりに原子が点欠陥となる割合を意味する。

\subsection{1 原子空孔濃度 $C_{\mathrm{V}}$, 格子間原子濃度 $C_{\mathrm{I}}$}

Fig. 1 に $C_{\mathrm{V}}, C_{\mathrm{I}}$ の濃度変化を示す. Fig. 1(a)を見ると， 照射量が $10^{-6} \sim 10^{-3} \mathrm{dpa} の$ 範囲で， $C_{\mathrm{V}}$ は極大值を取って いる.この極大の現れる主要因は原子空孔がボイドに吸収さ れることである.Fig. 2 に，ボイドの数密度および半径の変 化を示すが, Fig. 2 との比較から， $C_{\mathrm{V}}$ の極大の前後で，ボ イドの核形成と成長の優劣が変化していることがわかる。す なわら極大值より前の照射量では核形成が優勢で，極大值以 降では核成長が優勢となる。な扣，二次欠陥の形成・成長を 考慮しないモデルでは，極大は現れず $C_{\mathrm{V}}$ は一定となる．一 定となったときの $C_{\mathrm{V}}$ の值は，Fig. 1(a)の $C_{\mathrm{V}}$ の極大值と等 しい.

移動の活性化エネルギーの小さい格子間原子(Fig. 1(b)) は，原子空孔よりも少ない照射量 (例えば $P=10^{-10} \mathrm{dpa} / \mathrm{s} の$ ときは約 $10^{-11} \mathrm{dpa}$ )で濃度の増加が止まり，その後は静的 ンンクおよび点欠陥クラスターでの消滅によって濃度は減少 する． $C_{\mathrm{I}}$ に扔いて Fig. 1(a)の $C_{\mathrm{V}}$ の極大に対応するのは， 照射量が約 $10^{-6} \sim 10^{-4} \mathrm{dpa}$ の範囲にあらわれている $C_{I}$ の 減少の一時的な緩和である。 $C_{\mathrm{I}}$ は, 極大以降, 途中の減少 の緩和をはさんで単調減少しているが，転位ループの形成・ 成長に注目すると，緩和以前では核形成が優勢で，緩和以後 は成長が優勢となる.

\section{1 .2 点欠陥クラスター濃度および平均半径}

Fig. 2 と Fig. 3 に，ボイド・転位ループの濃度执よび半 径の変化を示す. Fig. 2(b)と Fig. 3(b)を比較すると, 前節 で述べたように，転位ループはボイドよりも少ない照射量で 


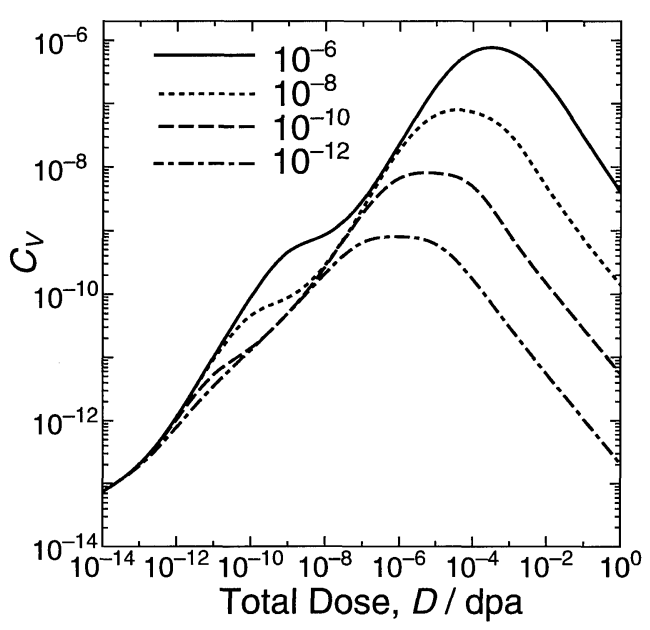

(a)

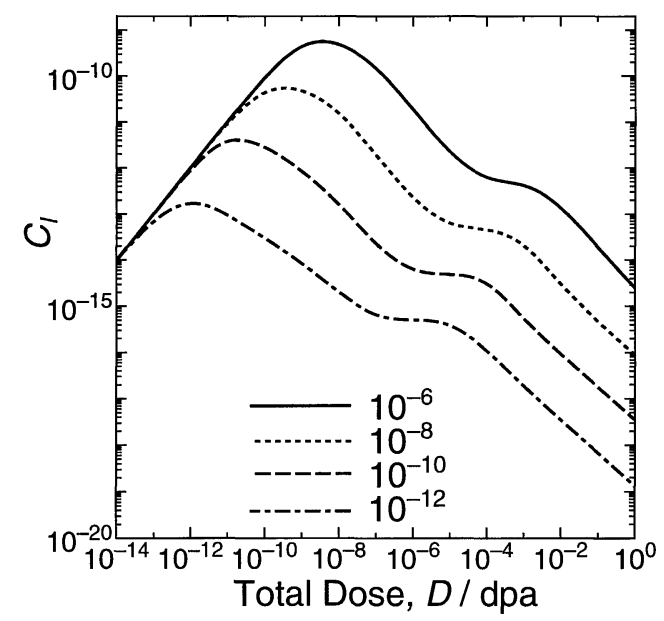

(b)

Fig. 1 Dose dependence of (a) vacancy concentration and (b) interstitial concentration. Numbers in the figure are damage rates $(\mathrm{dpa} / \mathrm{s})$.

成長が始まっていることがわかる。また，Fig. 3(b)におい て, $r_{\mathrm{IC}}$ はいったん減少し, その後再び増加に転じている. $r_{\mathrm{IC}}$ が極小值をとる照射量付近では， $C_{\mathrm{V}}$ が最大となっている ことから， $r_{\mathrm{IC}}$ が極小値をとる理由は原子空孔を吸収したた めと考えることができる.

照射の進行による $C_{\mathrm{VC}}, C_{\mathrm{IC}}$ の増加率が損傷速度によって 異なることにも注目する必要がある。すなわち, Fig. 2(a) 扣よびFig. 3(a)に見られるように，・損傷速度が速い汪ど 点欠陥クラスター濃度の立ち上がりが遅れる, ・損傷速度の 速い注ど点欠陥クラスター濃度の増加率は照射後期まで高 い，といら点である．損傷速度が速い注ど点欠陥クラスター 濃度の立ち上がりが遅れるのは，点欠陷複合体が同種点欠陥 を吸収する時間的余裕が少ないためである。また，損傷速度 の速い汪ど点欠陥クラスター濃度の高い増加率が照射後期ま で維持される理由は，以下のように考えることができる．照 射が進もにつれて点欠陥クラスタ一濃度の増加は鈍るが，こ れは点欠陥クラスターのシンク強度が点欠陥複合体全体のシ ンク強度よりも大きくなったためである。損傷速度が速い と, 点欠陷複合体の濃度も高くなるので, 点欠陥複合体全体



(a)

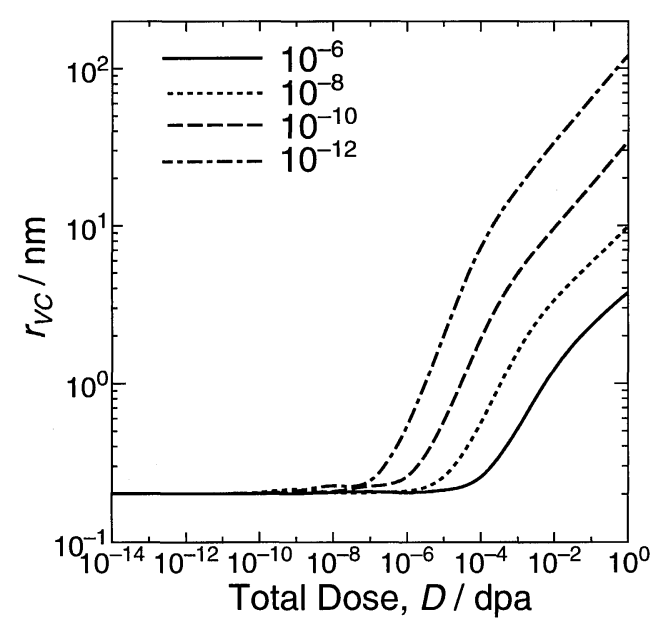

(b)

Fig. 2 Dose dependence of (a) void concentration and (b) void radius. Numbers in the figure are damage rates $(\mathrm{dpa} / \mathrm{s})$.

のシンク強度も大きく, 点欠陥クラスターのシンク強度がこ れを上回るには時間(照射量)がかかる。よって，点欠陥クラ スター濃度の高い増加率が照射後期まで維持されることにな る.これらのことから，「損傷速度の速い汪ど小さな点欠陥 クラスターが多く形成される」といら結果が得られるが，こ れは超高圧電子顕微鏡を用いた照射実験の結果とも符合して いる21).

\section{2 銅および銅クラスター形成に関する損傷速度依存性}

Fig. 4 に，銅原子特よび銅クラスターに関する計算結果を 示す．銅原子の拡散を考光る場合には，原子空孔の濃度だけ ではなく，原子空孔の移動回数が重要になる。損傷速度を下 げると, 同一の照射量に達するまでの照射時間が長くなり, かつシンク・点欠陥クラスターへの原子空孔の吸収頻度が低 くなることから, 原子空孔の総移動回数は, 損傷速度の小さ い核ど大きくなると予想される. Fig. 5 に原子空孔の総移動 回数 $\int M_{\mathrm{V}} C_{\mathrm{V}} \mathrm{d} t$ の計算結果を示す.

Fig. 4(a)を見ると，損傷速度の低い領域では，銅濃度の 顕著な減少が見られるのに対し, 損傷速度の大きい領域, 特 


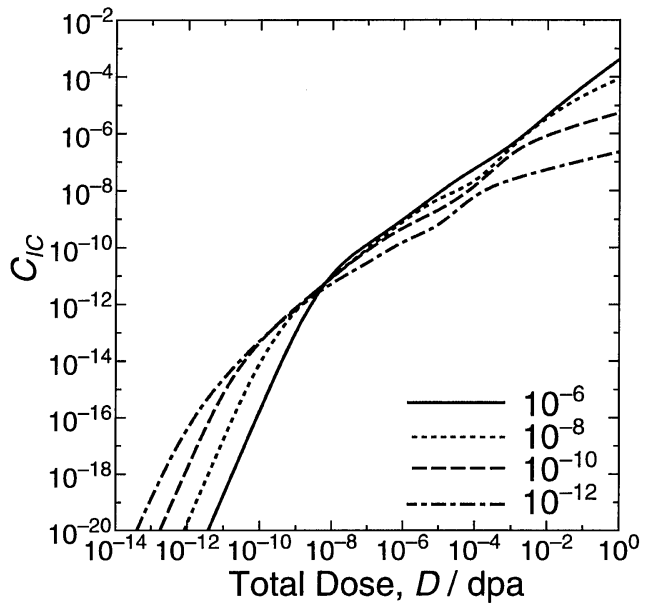

(a)

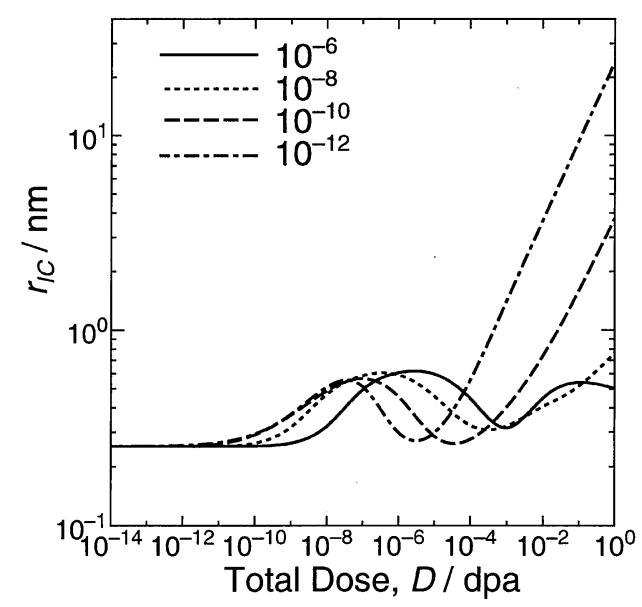

(b)

Fig. 3 Dose dependence of (a) I-loop concentration and (b) I-loop radius. Numbers in the figure are damage rates (dpa/s).

に $P>10^{-8} \mathrm{dpa} / \mathrm{s}$ の領域では, 照射量が大きくなっても銅濃 度は汪とんど变化していないことがわかる。これは銅濃度の 変化は原子空孔濃度ではなく $\int M_{\mathrm{V}} C_{\mathrm{V}} \mathrm{d} t$ に依存するためであ る. 初期銅原子濃度が 0.6 at\%で, 銅原子が均一に分布し ているとすると, ある 2 つの銅原子間の距離は約 7 原子間 距離である. 従って, 銅原子対を形成するためには, 平均し て $7^{2} \sim 50$ 回程度の移動を必要とすると考えられる. 実際,

Fig. 5(b)に揖いて, $\int M_{\mathrm{V}} C_{\mathrm{V}} \mathrm{d} t$ が50回を上回るところの照射 量を見ると, 損傷速度の低いときほど少ない照射量で上回っ ていることから, 損傷速度が低くなると銅の析出が促進され ると考えることができる，一方，損傷速度が大きい場合は， 原子空孔の数自体は多いが，原子空孔が移動できるだけの十 分な時間がないため, 銅原子の移動も起こりにくくなってい ると言える。

Fig. 4(c)に示した $r_{\mathrm{CuC}}$ の損傷速度依存性は, 值の変動の 幅はボイド・転位ループに比べて小さい。しかし， $C_{\mathrm{CuC}}$ の 依存性が高いことに注目しなければならない(Fig. 4(b)). 損傷速度が $10^{-10} \mathrm{dpa} / \mathrm{s}$ より小い領域では， $C_{\mathrm{CuC}}$ は照射の 比較的初期（照射量～ $0.01 \mathrm{dpa}$ )飞飽和する. このことは，4 個以上の銅原子で構成された銅クラスターからは銅原子の解

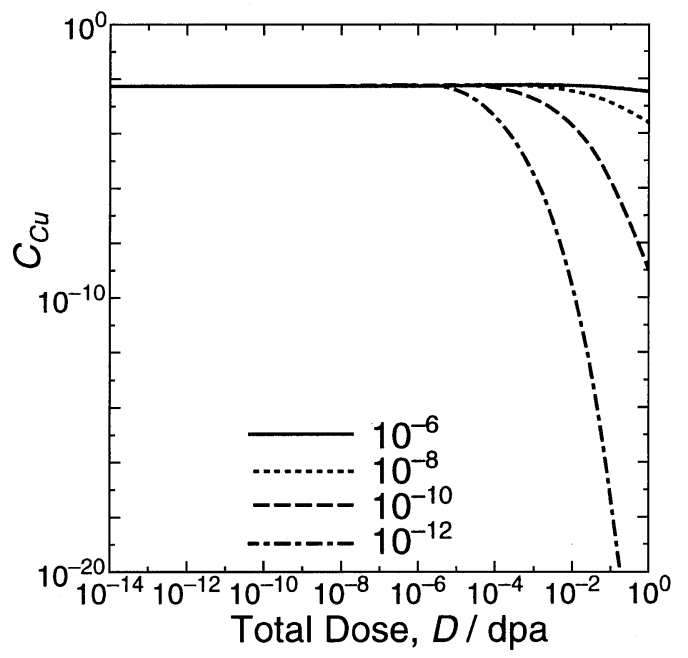

(a)

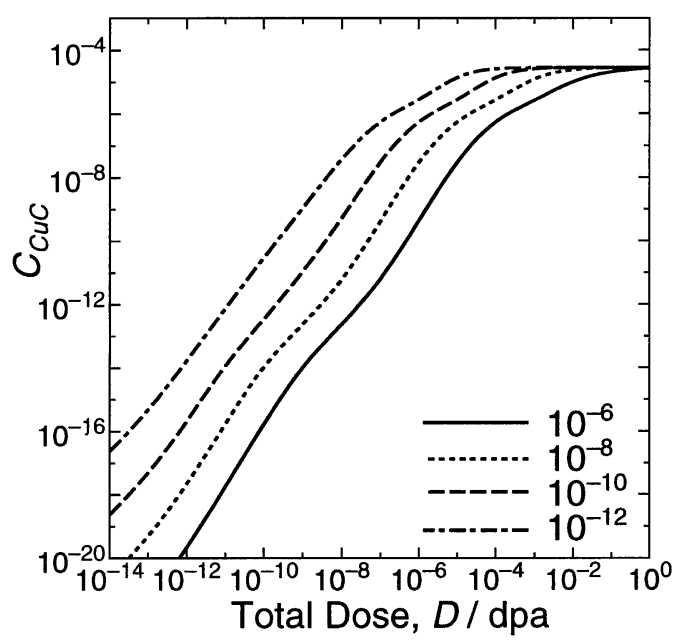

(b)

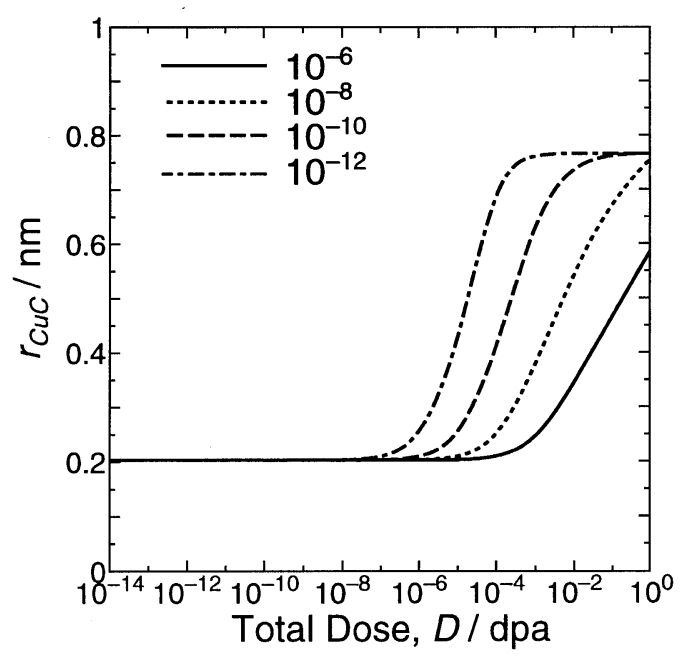

(c)

Fig. 4 Dose dependence of (a) isolated copper concentration, (b) copper cluster concentration and (c) average radius of copper cluster at initial copper content $C_{\mathrm{Cu}}^{0}=0.6$. Numbers in the figure are damage rates $(\mathrm{dpa} / \mathrm{s})$. 


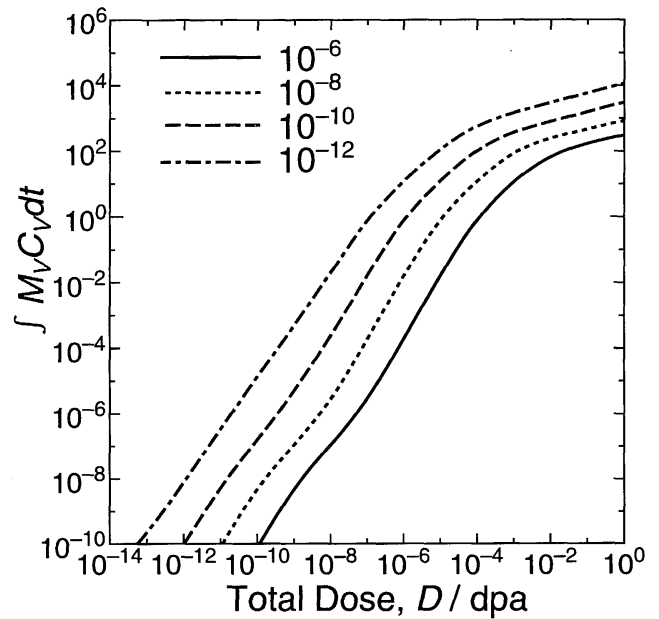

(a)

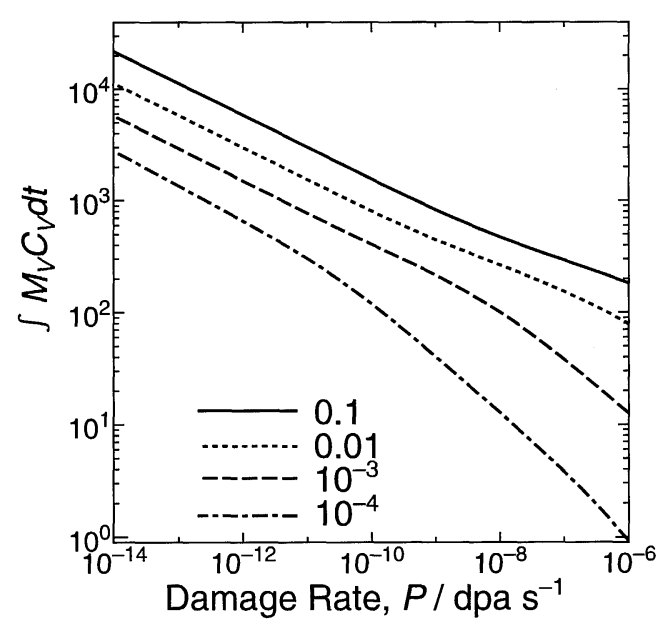

(b)

Fig. 5 (a) Dose dependence and (b) damage rate dependence of $M_{\mathrm{V}} C_{\mathrm{V}} \mathrm{d} t$. Numbers in the figure are (a) damage rates $(\mathrm{dpa} / \mathrm{s})$ and (b) total doses (dpa).

離はしないといら本モデルの仮定にも関係している可能性も あるが，今回計算した損傷速度の全範囲にわたって， $C_{\mathrm{CuC}}$ は， $C_{\mathrm{VC}}$ や $C_{\mathrm{IC}}$ と等しいか，または高い，損傷速度の低い領 域において，この傾向は顕著である。

\section{3 降伏応力変化の損傷速度依存性}

Fig. 6 に，すべての点欠陥クラスターにOrowan モデルを 適用して計算した降伏応力変化 $\Delta \sigma_{\mathrm{y}}$ の損傷速度依存性を示 す. Fig. 6(c)には発電用原子炉の圧力容器がその想定寿命 までに受ける照射量に相当する $0.1 \mathrm{dpa}$ の場合の計算結果の 詳細を示す. Fig. 6(c)に扣いて, 損傷速度の低い汪ど銅ク ラスターの $\Delta \sigma_{\mathrm{y}}$ への寄与が大きくなるのに対し, 転位ルー プ拉びボイドの $\Delta \sigma_{\mathrm{y}}$ への寄与は損傷速度の高いほど大き くなっている。転位ループ・ボイドの核形成は主にカスケー ドによる複合体形成によって起こるので，損傷速度の大きい ほど $\Delta \sigma_{\mathrm{y}}$ への寄与は大きくなると言える。しかしながら， 転位ループ・ボイドの $\Delta \sigma_{\mathrm{y}}$ への寄与の絶対值は銅クラスタ 一の寄与よりも小さいので, $0.1 \mathrm{dpa}$ 程度の照射量では転位 ループ・ボイドは全体の $\Delta \sigma_{\mathrm{y}}$ には大きな影響を及ぼさない。

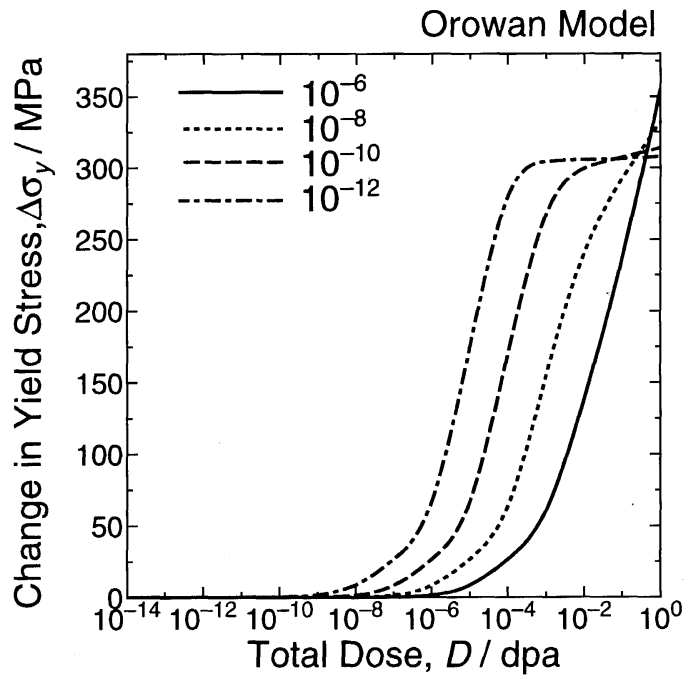

(a)

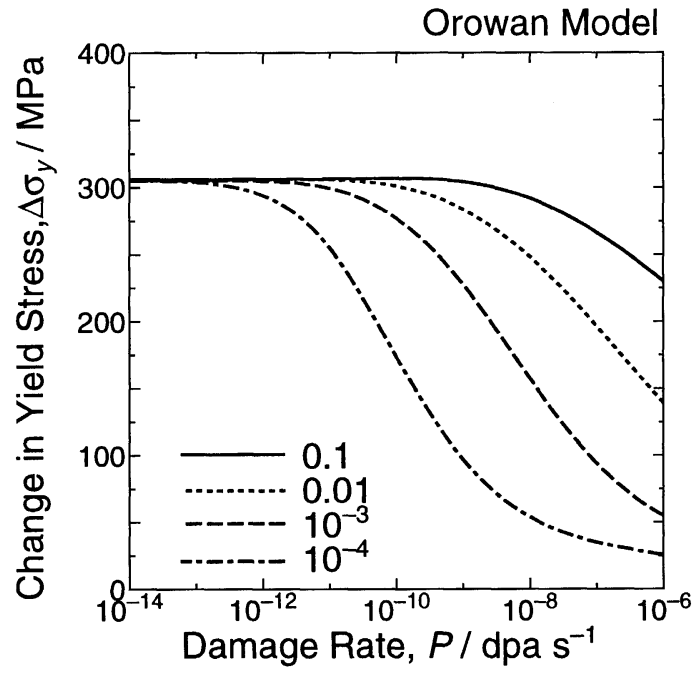

(b)

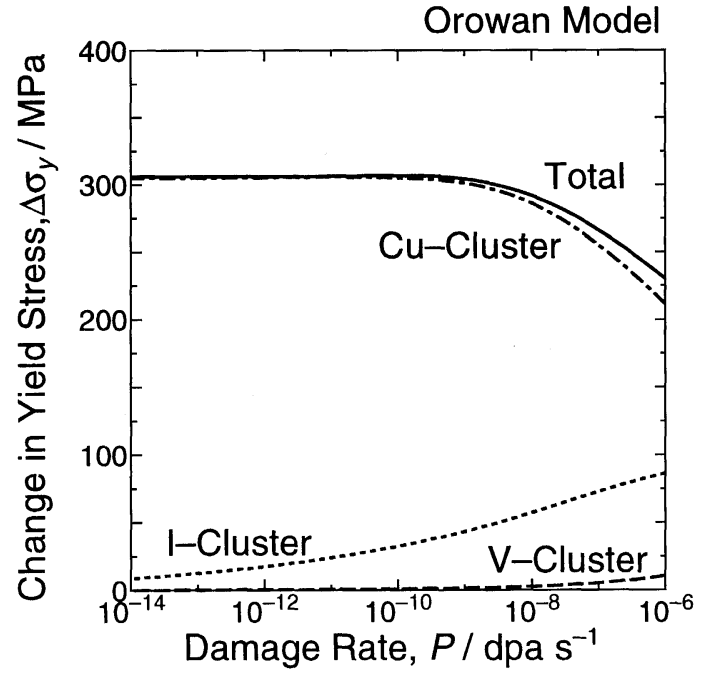

(c)

Fig. 6 Dose dependence (a) and damage rate dependence (b) of yield stress change $\Delta \sigma_{\mathrm{y}}$ using Orowan model for effect of $\mathrm{Cu}$ cluster. (c) shows the contribution of each factor to the $\Delta \sigma_{\mathrm{y}}$ in Dose $=0.1 \mathrm{dpa}$. Numbers in the figure are (a) damage rates (dpa/s) and (b) total doses (dpa). 
Fig. 7 に，銅クラスターに Russel-Brown モデルを，ボイ ドと転位ループについては Orowan モデルを, それぞれ適 用して計算した $\Delta \sigma_{\mathrm{y}}$ の損傷速度依存性を示す. Fig. 7 には, Orowan モデルのときと同様, 損傷速度の低い核ど銅クラス ターの $\Delta \sigma_{\mathrm{y}}$ への寄与が大きくなる傾向が見られるが，その 割合および銅クラスターの寄与の絶対值は, Orowan モデル に比べて小さくなっている. Fig. 7 (c) に照射量が $0.1 \mathrm{dpa} の$ とさの各二次欠陥の寄与を示すが, 全体の值(図中 Total) は 損傷速度にあまり依存しないように見えても, その構成割合 は損傷速度によって大きく異なっている．Fig. 7(c)に抹い て, 計算結果をその支配要因で区分すると, 損傷速度の低い 順に, $\mathrm{Cu}$-cluster 支配領域, 遷移領域, I \& V-cluster 支配 領域と分けることができる。

\section{4. 考察}

\section{1 モデルの妥当性}

本モデル㧊よびその結果の妥当性に大きな影響を与える要 素として，・反応速度論に基づいたモデルであること，・銅 原子と原子空孔との結合エネルギーを０としていること， ・カスケード損傷の効果を定数 $(\mathrm{C} / \mathrm{P}$ 比)で記述しているこ と, ・4 個以上の点欠陥で構成されるクラスターを熱的に安 定な点欠陥クラスターとしていること, が挙げられる. 固体 中の拡散に反応速度論を適用する場合には, 小岩22)が指摘 するよらに，その適用範囲に注意する必要がある。本モデル では点欠陥濃度は低いものの常に一定割合で点欠陥が形成さ れるとして扣り, 点欠陷濃度の均一化といら反応速度論の前 提注涪成り立っていると考えられる。 $\mathrm{Cu}-\mathrm{V}$ 結合ェネルギー を 0 としている点は, 銅の析出が降伏応力変化の主要因で あることを考学るとかなり粗い仮定のように見える。 $\mathrm{Cu}-\mathrm{V}$ 結合エネルギーを考慮すればより正確なモデルとなることは 確かである。しかしながら，モデルの説明のところで述べた よらに, $\mathrm{Cu}-\mathrm{V}$ 相互作用は銅原子・原子空孔の拡散を遅くす る働さが主であり，損傷速度依存性を議論する上では重大な 影響は及ぼさない， $\mathrm{C} / \mathrm{P}$ 比については，中性子照射した試料 の TEM 観察の結果等から妥当と考兄られる值を用いている が， $\mathrm{C} / \mathrm{P}$ 比そのものが損傷速度依存性を持つことは十分考光 られる. C/P 比の損傷速度依存性が小さければ本研究の結果 と大きな違いはないが，大きい場合には例光ば $\Delta \sigma_{\mathrm{y}}$ の損傷 速度依存性が変化することになる，変化の方向や大きさにつ いては今後の検討が必要である．点欠陥集合体の熱的安定性 は議論の分かれるところであるが，本モデルはカスケード損 傷と点欠陷微小集合体の熱的不安定性を取り入れた最も簡単 な場合として構築したものである．熱的に不安定とみなす集 合体の大きさを变えても損傷速度依存性が現れなくなるとは 考觉にくい.

\section{2 加速照射試験の妥当性}

Fig. 6 扎よびFig. 7 に括いて，ボイド・転位ループと銅 クラスターでは, 各々の降伏応力変化の損傷速度依存性が全 く異なっている.ボイド・転位ループは主にカスケードによ る点欠陥複合体形成が主要な形成過程であるのに対し，銅ク

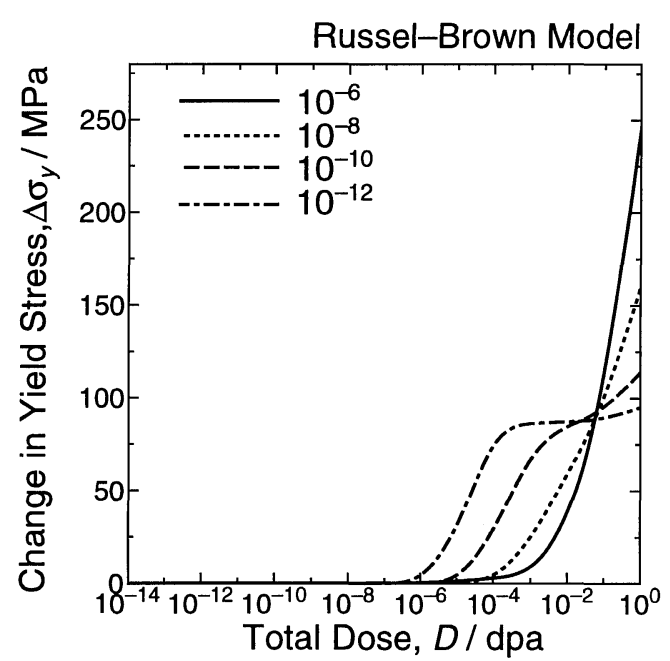

(a)

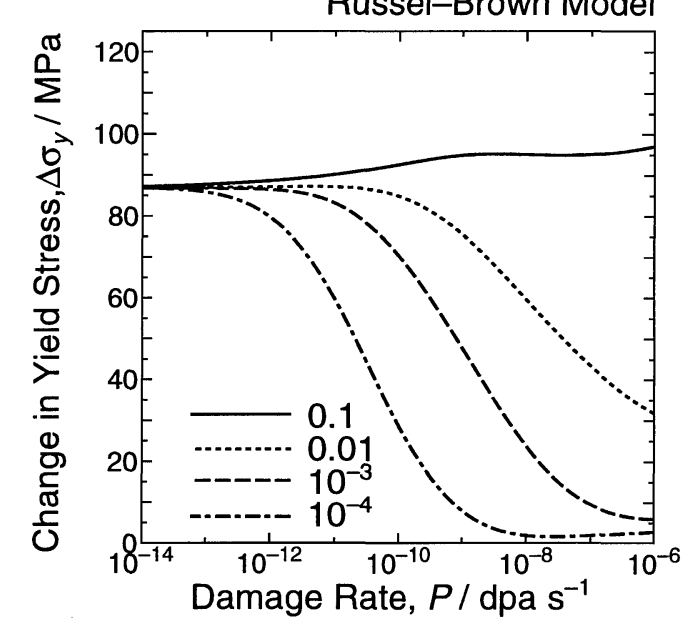

(b)

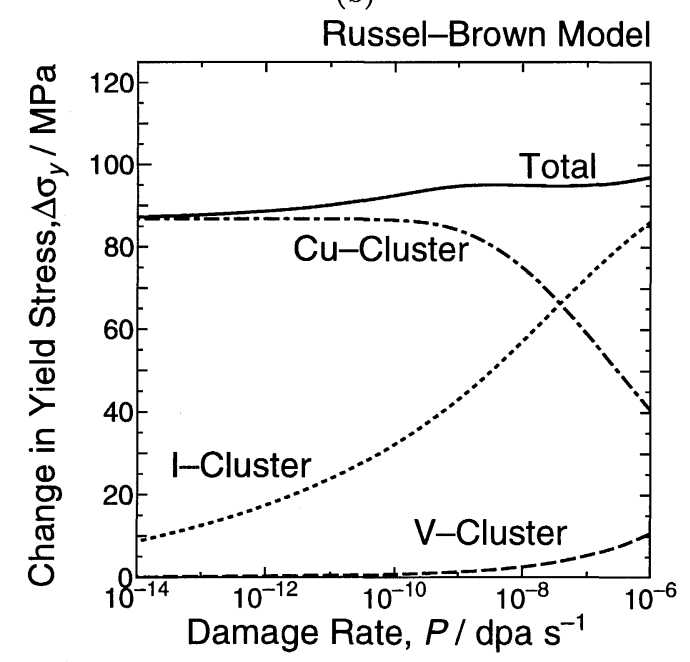

(c)

Fig. 7 Dose dependence (a) and damage rate dependence (b) of yield stress change $\Delta \sigma_{\mathrm{y}}$ using Russel-Brown model for effect of $\mathrm{Cu}$ cluster. (c) shows the contribution of each factor to the $\Delta \sigma_{\mathrm{y}}$ in Dose $=0.1 \mathrm{dpa}$. Numbers in the figure are (a) damage rates (dpa/s) and (b) total doses (dpa).

ラスターは原子空孔を介した銅原子の拡散によるものが主要 な形成過程である. 本モデルでは, ボイド・転位ループにつ いては, 単位時間あたりの点欠陥複合体形成率は点欠陥形成 
率に比例するとしているので, 損傷速度が速いとボイド・転 位ループの濃度は高くなることが予想されるが, 計算結果も その傾向を示している(Fig. 2(a), Fig. 3(a))。一方，銅クラ スターは銅原子の移動によってのみ形成されると仮定してい るので, 銅原子の移動を媒介する原子空孔の総移動回数 $\int M_{\mathrm{V}} C_{\mathrm{V}} \mathrm{d} t$ が銅クラスターの形成・成長を支配していると言 える(Fig. 5)，異なる損傷速度依存性持った要因が重なりあ った結果が全体の $\Delta \sigma_{\mathrm{y}}$ なので, $\Delta \sigma_{\mathrm{y}}$ の損傷速度依存性の図 には，各要因の絶対值にもよるが，遷移領域は必ず現れると 言える. Fig. 7(c) は, 加速照射試験を行った場合，材料の マクロな性質 $\left(\Delta \sigma_{\mathrm{y}}\right.$ など)が同一でも，その原因が全く異なる ことがありらることを示唆している。 また, 一般の発電用原 子炉の損傷速度は $\mathrm{Cu}$-cluster 支配領域にあるので，加速照 射試験の結果をよく検討しないと, 性質変化・寿命予測に拉 いて危険側の結果(実機の照射脆化が予測より早く起こって しまう)を出す可能性がある.

\subsection{Orowan モデルと Russel-Brown モデルの比較}

Stoller の研究8)をはじめとして, 銅クラスターによる降伏 応力 (せん断応力) の変化は, 一般に Russel-Brown モデル で説明されている. Russel-Brownモデルに拈ける $\Delta \sigma_{\mathrm{y}}$ l $\sqrt{f_{\mathrm{ppt}}}\left(f_{\mathrm{ppt}}\right.$ は析出物の体積分率 $)$ と析出物半径の関係は Orowan モデルと似ているが，その絶対值が異なる。な抏， $\Delta \sigma_{\mathrm{y}}$ を $\sqrt{f_{\mathrm{ppt}}}$ で規格化するのは, 析出物の数密度の影響を取 り除くためである8). Orowan モデルの方が絶対值は大きく， 特に析出物半径が $1 \mathrm{~nm}$ よりさいところではその差は顕著 になる. 析出物半径 $0.5 \sim 1 \mathrm{~nm}$ 程度では, 両者の比 $\Delta \sigma_{\mathrm{y}}$ (Orowan) $/ \Delta \sigma_{\mathrm{y}}$ (Russel-Brown) は約1.5〜2.5である. Orowan モデルの方が，最大 2.5 倍ほど安全側の計算結果を示す ことになる。

Fig. 6 と Fig. 7 を比較すると， $\Delta \sigma_{\mathrm{y}}$ の絶対值は RusselBrown モデルを適用した Fig. 7 の方が小さい. Orowan モ デルでは，障害物(ここでは銅クラスター)の数密度変化が $\Delta \sigma_{\mathrm{y}}$ に大きな影響を及ぼすので，銅クラスターの数密度が非 常に高い場合は照射のごく初期から $\Delta \sigma_{\mathrm{y}}$ は高い値を示す.

しかし，Fig. 4(c)に示す程度の半径を持つ銅クラスタ一は 母相と整合していることが分子動力学法によるモデル計算か ら示唆されて扣り 23)，転位の運動に対する強い障害になる とは考えられない.よって, Russel-Brown モデルの方が， 特に照射初期に拈いては，より現実に近い状況を提示してい ると言える。しかし，照射のすべての段階に掞いて， Russel-Brown モデルを用いることには無理があると考えら れる.Fig. 4(a)を見ると，損傷速度の遅い $\left(P<10^{-10}\right.$ $\mathrm{dpa} / \mathrm{s})$ 場合は，照射後期にほとんど全ての銅原子が析出して いることがわかる．銅原子の析出が終わった後は，銅クラス ターは Ostwald 成長によって数密度および半径分布を変え ることが予想される，鉄中の銅クラスターは，半径が $3 \mathrm{~nm}$ 程度になると相変態を起こし始め, 母相との整合性を失 523)が，銅クラスターが原子空孔を多く含んでいた場合は， これょりも小さい半径で相変態を起こすことも考えられる.

ともかく, 母相との整合性のない析出物は, 転位の運動に対 する強い障害となるので, Orowan モデルの適用が有効と言
える. 将来，ある半径 $r$ を持つ銅クラスターのらち，どの程 度が相変態を起こすかが明確にされれば, Orowan モデルと Russel-Brown モデルを併用することにより，より精度の高 い $\Delta \sigma_{\mathrm{y}}$ の評価がでさると考学られる.

また，照射後期に扣いては，Russel-Brown モデルからの ずれが生じる可能性がある. Russel-Brown モデルには転位 の外側のカットオフ半径 $r_{\mathrm{c}}$ なる変数があるが, 通常これは 定数として扣り，例光ば Stoller は，ネットワーク転位の密 度 $\rho_{\mathrm{n}}$ を使って $r_{\mathrm{c}}=1 / \sqrt{\pi \rho_{\mathrm{n}}}$ としている ${ }^{8)}$. この式によると， 転位密度が大きくなると $r_{\mathrm{c}}$ は小さくなり， $\Delta \sigma_{\mathrm{y}}$ は大きくな る．転位ループが成長してくると，転位ループの合体や unfault が起こるので, $\rho_{\mathrm{n}}$ が低い場合には, 転位ループの存在 は無視できないと考觉られる。転位ループの存在を考慮する と, 上記の式で計算した $\Delta \sigma_{\mathrm{y}}$ は考慮しない場合より大きく なる。

銅クラスターの取り扱いが大きく異なるにもかかわらず, 本モデルと Stoller のモデルは同じ傾向を示している. 二次 欠陥の形成過程といら点からは Stoller のモデルの方がより 厳密であるが，特に損傷速度の遅い場合に执いて，格子間原 子クラスターの $\Delta \sigma_{\mathrm{y}}$ への寄与は小さいことから, 全体の傾 向を知る上では本モデルの近似も有効であると考学られる.

Stoller は，格子間原子クラスターについては，その大きさ ごとに式を立てて濃度の時間変化を計算している， $\Delta \sigma_{\mathrm{y}} へ の$ 寄与の割合から考えると，この取り扱いを銅クラスターに対 しても適用すれば，反応速度論に基ついたモデル計算の有効 性をより高められると考觉られる。

\section{5. 結言}

$\mathrm{Fe}-\mathrm{Cu}$ 合金の照射下での二次欠陥形成に損傷速度が及ぼ す影響を調べるために, 反応速度論に基ついたモデル計算を 行った．計算の結果から，以下の結論が得られた。

（1）転位ループ・ボイドについては，同一照射量に执い て, 損傷速度が速いほど, 核形成は促進されるが核成長は抑 制される.これは転位ループ・ボイドの核形成の多くがカス ケードに由来するためである. また, 降伏応力変化への寄与 は，損傷速度の速いほど大きい。

（2）銅クラスターについては, 銅原子の移動回数が損傷速 度の遅い汪ど多くなるため, 同一照射量に执いて, 損傷速度 の遅い汪ど, 核形成・核成長ともに促進され, 降伏応力変化 への寄与も大きくなる.

（3）銅クラスターの平均半径の計算結果からは, 銅クラス ターは母相と整合性を持つと考兵られ, $\mathrm{Fe}-\mathrm{Cu}$ 合金の降伏 応力を計算する場合, 銅クラスターにはOrowan モデルよ りもRussel-Brown モデルを適用する方が適当であるとい える、しかし，条件によっては Russel-Brown モデルが必 ずしも成り立たない可能性も考光られるため，銅クラスター のサイズ分布などを考慮したより厳密な検討が必要である.

（4）Russel-Brownモデルを用いて降伏応力変化を見積も ったところ, $P=10^{-8} \mathrm{dpa} / \mathrm{s}$ 付近に遷移領域が現れ, これを 挟んで降伏応力変化の主要因が異なるといら結果が得られ た. 加速照射試験と実際の原子炉圧力容器の照射条件は, こ 
の遷移領域を挟む位置にあるため, 加速照射試験の結果の解 釈には注意を必要とする。

\section{文献}

1) T. Kodaira: Nuclear Engineering, 30 (1984), No. 4, 81-87.

2) J. R. Hawthorne and A. L. Hiser: ASTM STP, 1046(1990), Vol. 2, 55-79.

3) K. Kussmaul, J. Föhl and T. Weissenberg: ASTM STP, 1046 (1990), Vol. 2, 80-104.

4) C. A. English, W. J. Phythian, J. T. Buswell, J. R. Hawthorne and P. H. N. Ray: ASTM STP, 1125(1992), 93-116.

5) R. K. Nanstad, K. Farrell, D. N. Braski and W. R. Corwin: J. Nucl. Mater., 158(1988), 1-6.

6) M. Kiritani: J. Nucl. Mater., 169(1989), 89-94.

7) R. E. Stoller: ASTM STP, 1175(1993), 394-423.

8) R. E. Stoller: ASTM STP, 1270(1996), 25-58.

9) The Atomic Energy Society of Japan: Report of the Research of Mechanism on Irradiation Embrittlement of Reactor Pressure Vessel $(I) \sim(I V)$, The Atomic Energy Society of Japan, (1993-1996), pp. 1-47.

10) R. Sizmann: J. Nucl. Mater., 69 \& 70 (1978), 386-412.

11) J. S. Köhler, F. Seitz, W. T. Read Jr., W. Shockley and E.
Orowan: Dislocations in Metals, AIME, (1954), pp. 129-134.

12) K. C. Russel and L. M. Brown: Acta Metall., 20(1972), 969974.

13) E. Fujita: Lattice Defects, Asakura Publishing, (1980), pp. 6168.

14) W. Hume-Rothery: The Structures of Alloys of Iron : an Elementary Introduction (Japanese Edition), Kyoritsu Publishing, (1968), pp. 280-302.

15) E. Fujita: Physical Metallurgy, AGNE Technical Center, (1996), pp. 218-221.

16) J. Z. Jiang, U. Gonser, C. Gente and R. Bormann: Appl. Phys. Lett., 63(1993), No. 8, 1056-1058.

17) H. W. King: J. Mater. Sci., 1(1966), 79-90.

18) S. Ishino: Radiation Damage, Univ. of Tokyo Press, (1979), pp. 149-152.

19) N. Soneda and T. Diaz de la Rubia: Phil. Mag. A, 78 (1998), No. 5, 995-1019

20) S. D. Cohen and A. C. Hindmarsh: Computers in Physics, 10 (1996), No. 2, 138-143.

21) N. Yoshida and M. Kiritani: J. Phys. Soc. Japan, 35 (1973), No. $5,1418-1429$.

22) M. Koiwa: Solid State Physics, 8(1973), No. 3, 119-130.

23) M. Ludwig, D. Farkas, D. Pedraza and S. Schmauder: Modeling and Simulation in Material Sciences and Engineering, 6(1998), No. 1, 19-28. 